by Maria Bascik ${ }^{l}$, Wojciech Chelmicki ${ }^{1 *}$ and Jan Urban ${ }^{2}$

\title{
Geoconservation of Springs in Poland
}

\author{
${ }^{1}$ Jagiellonian University, Institute of Geography and Spatial Management, ul. Gronostajowa 7, 30-387 Kraków, Poland \\ *Email: w.chelmicki@uj.edu.pl \\ ${ }^{2}$ Polish Academy of Sciences, Institute of Nature Conservation, al. A. Mickiewicza 33, 31-120 Kraków, Poland
}

Springs are unique phenomena that document water circulation conditions. Their economic importance and use often gives rise to the degradation of their natural features. But they should be understood as a form of natural heritage and protected like other abiotic elements of nature. According to the Polish Act for Nature Conservation (2004), nature parks and nature reserves are the most effective legal means of protecting springs. Springs are the most valuable elements of the several nature reserves located in the Polish mountains, uplands, and lowlands. The most popular type of legal protection of individual springs is that of "nature monument". At the beginning of 2008, 134 springs were protected in this way - representing $7 \%$ of abiotic nature monuments and $0.4 \%$ of the total number of monuments in Poland. The number of monuments of this type has increased greatly in recent times due to the activity of several scientific groups and that of local governments as well. The distribution of springs as nature monuments varies greatly in Poland. Most of them are located in the Carpathian Mountains and in the southern Polish uplands. The legal protection of springs should help prevent their persistent destruction, especially if it stimulates the consciousness of local residents as well as authorities.

\section{Introduction}

The nature conservation is motivated above all by a concern for nature, learning, aesthetics, culture, and education whereby each element of nature is regarded as an integral part of a whole. Based on this philosophical approach to conservation, nature is a form of heritage that needs to be handed down to future generations in the spirit of sustainable development. So defined, this heritage comprises both living and inanimate nature that needs protection (Dingwall et al., 2005).

The idea of nature conservation dates back to the earliest history of humankind. In the religious beliefs of tribes and peoples, old trees and hidden spots in the forest and springs were regarded as sacred and untouchable which helped these objects survive intact. As civilizations progressed, economic motives for the protection of natural resources appeared while a conservationist approach to nature emerged in connection with the development of the natural sciences.
Its beginnings tend to be linked to Alexander Humboldt who introduced the term "nature monument" in 1819 (Naturdenkmal, Monument de la Nature).

Nature conservation is concerned with a variety of natural features and phenomena. The spectrum of inanimate features subject to conservation and protection includes the Earth's crust (structures, rocks, and minerals), Earth history and life forms, landforms, and contemporary geological, geomorphological, and hydrological processes (Gray, 2003). Springs fit in very well with the idea of the Earth's geodiversity, because as natural and concentrated outflows of water on the surface, they combine processes within the Earth's crust (conditioned by its structures) with the surface natural environment (and the impact on its morphology and organic life). Springs also constitute a very important and traditional cultural component. For these reasons, springs deserve a special degree of legal protection.

The aim of this paper is to present current issues in the geoconservation of springs in Poland, its effectiveness, and the problems arising from increasing human pressures.

\section{The Need for Non-economic Protection of Springs}

Springs are natural features that offer information about the groundwater environment without the need for costly drilling operations. Spring water conditions such as their discharge, temperature, chemistry, and organic life change under the influence of natural and anthropogenic factors. Springs also influence the natural environment by affecting the local landforms and modifying the humidity levels in the soil and air, thus impacting the habitats of plants as well as wildlife (Springer and Stevens, 2009). The impact of a spring goes far beyond its physical dimensions at its point of emergence. Springs appear in various forms and they function as kind of environmental islands that influence the landscape and sometimes enrich it with special qualities. Springs also function in the cultural dimension as evidenced by the names given to them and their linkage to local popular traditions and beliefs as far back as Greek mythology (Mariolakos, 1998). Such traditions have also been continued in Christianity (Ball, 2004). For example, according to local beliefs, some springs have been associated with holy persons and/or various miraculous properties (e.g. the St. Vincent Kadlubek Spring near Sandomierz in the Swietokrzyskie Mountains in south-central Poland - Gagol and Urban, 2000; and several springs in the CracowCzestochowa Upland in southern Poland - Bascik and Chelmicki, 2002). Historically, such special motivations were usually behind the first practical, although informal, forms of protection given to springs. Currently, springs are most often protected as sources of water for drinking and economic use. Given the large scale of these purposes, springs are usually reconstructed in a way that eliminates their natural 
character. They are also sometimes assigned protection as habitats of rare, unique, or special types of biota. However, the most prominent of motivations for their conservation should consider, first of all, the scientific-educational meaning of springs as abiotic objects, i.e. springs as features which evidence the existence of groundwater in the Earth's crust and illustrate the mechanisms and rules governing its circulation. The educational role of springs is of special importance because of the widespread lack of understanding of the meaning of groundwater quality and quantity for human life and the world economy caused by a number of reasons (Ball, 2004).

While spring research has recently tended to gain in popularity, the number of publications on strategies for spring conservation remains relatively small. Most studies that are available are linked to large karst springs or to particularly valuable mineral springs.

Springs are not listed as a unique natural feature category on the World Heritage List (Dingwall et al., 2005; Kozina, 2008). The features closest to springs listed among the categories of the World Heritage List are karst and fluvial systems.

There are very few national parks or nature reserves worldwide where springs constitute the main features protected. Northern Florida is unique with its large number of spectacular karst springs. With approximately 600 springs, it ranks as one of those areas with the greatest concentration of this feature anywhere in the world. These springs are also under threat from pollution and increasing tourism because of Florida's increasingly high population density. In 1999 and 2000, the Florida Department of Environmental Protection mandated a Florida Springs Task Force to develop a strategy focused on: outreach, information, management, regulation, and funding (Hartnett, 2000). This strategy strongly highlights the need for citizen participation through the education of students, citizens, and local leaders about the value, function, and protection needs of springs. The conservation of the biotic aspects of springs are also strongly targeted in the western United States. One of the main spring resource management goals has been designated as "the education of the public about the importance of springs through interpretive, watchable wildlife, and other environmental education programs" (Sada et al., 2001).

New Zealand has become another region for studies of management and conservation strategies for coldwater springs (Scarsbrook et al., 2007; Barquin and Scarsbrook, 2008). The effective management of springs was to be achieved by recognizing the full range of environmental and societal values associated with spring habitats, understanding threats to the sustainability of these values, and formulating strategies that provide a balance between potentially conflicting uses.

A database of springs is a proper first step towards their efficient protection. The German province of Brandenburg has a database containing more than 700 sites (Groever et al., 1996). In New Zealand, the Canterbury administrative district database known as ECAN has more than 1500 springs listed. The New Zealand Freshwater Society has a database of 426 springs (Scarsbrook et al., 2007). The Italian CRENODAT database covers the Alpine region of Trentino (Cantonati et al., 2005).

\section{Springs against the Backdrop of Geodiversity and Landscape Diversity in Poland}

The geological and landscape diversity of Poland is conditioned, in general, by its location within the so-called Trans-European Suture
Zone (TESZ) and within the marginal zone of the Pleistocene icesheet expansion. The first factor resulted in an almost continuous record of the history of tectonic events between East European Platforms and western and central European geological units during the Caledonian, Variscan, and Alpine cycles. The second factor significantly influenced the diversity of the landscape and near-surface rocks (Slomka, 2008). Both of these factors have affected the hydrogeological conditions in Poland and thus the distribution of springs across Polish territory.

The predominant geomorphological factors which shaped the surface of the land of northern and central Poland (covering ca 2/3 of the area of the country) were Pleistocene ice-sheets. The young postglacial landscape of the coastlands and lakelands in northern Poland, formed during the last Pleistocene glaciation (Würm=Vistulian), is characterised by the occurrence of different types of post-glacial hills and hill ridges, dunes, as well as glacial trough lakes (Fig. 1). The pre-Quaternary rocks in this area are covered with a thick blanket of sandy-clayey glaciofluvial and glacial sediments bearing erratic boulders as well as aeolian sands in places (Kondracki, 2000; Alexandrowicz et al., 2004; Mojski, 2005). Groundwater occurs within the sand and gravel and its circulation is directly linked to relief and surface bodies of water such as lakes. Springs are irregularly distributed throughout this region - found especially often on the slopes of proglacial stream valleys (e.g. Fac-Beneda and Hryniszak, 2007). The geological structure of the Quaternary cover in central Poland is, in general, similar to that in the northern part of the country. However, the old glacial landscape of this region, transformed by denudation processes, is usually more flat (Alexandrowicz et al., 2004; Mojski, 2005) and thus less favourable to the existence of springs. Nevertheless, there are some micro-regions which do abound in springs, e.g. the Lodz region (Moniewski, 2004).

The landscape of the hilly uplands located in southern and central Poland (south of the region covered by the thick blanket of Quaternary sediment) has been conditioned by Alpine and older geological structures. In this particular area, structures have been built of a wide range of lithified and predominantly sedimentary rocks of different ages. Rocks representing almost all geological periods from the Cambrian to the Quaternary (with the exception of Paleogene) crop out in the Swietokrzyskie (Holy Cross) Mountains located just within the TESZ and in the Nidzianska Basin. Both regions are important components of the Malopolska Upland. The older of the rocks, affected by the Caledonian and Variscan tectonic movements, are significantly folded and faulted (Urban and Gagol, 2008). The Slasko-Krakowska Upland (west of the Malopolska Upland) represents an Alpine platform comprises of Mesozoic rocks (Cracow-Silesian Monocline Matyszkiewicz, 2008) with an Upper Paleozoic Variscan core (Silesian Basin). The third (eastern) region of the upland belt - the Lubelska Upland - is also an Alpine platform with the surface made of Cretaceous rocks. These rocks are overlaid with marine Neogene sediments in the southern part of this region - called the Roztocze Upland (Buraczynski, 1997; Radwanek-Bak and Bak, 2008). Major aquifers in these upland regions are found in thick series of karstified carbonates of the Middle and Upper Devonian (limestone and dolomite), Upper Jurassic (limestone), Upper Cretaceous (marl, gaize, chalk, and limestone), and Middle Triassic (limestone and dolomite). However, pore-fissured aquifers also do occur within Carboniferous siliciclastic rocks of the Silesian Basin as well as in Permian, Lower Triassic, and Lower Jurassic sandstone-siltstone series of the Swietokrzyskie Mountains (Paczynski and Sadurski, 2007). Springs 


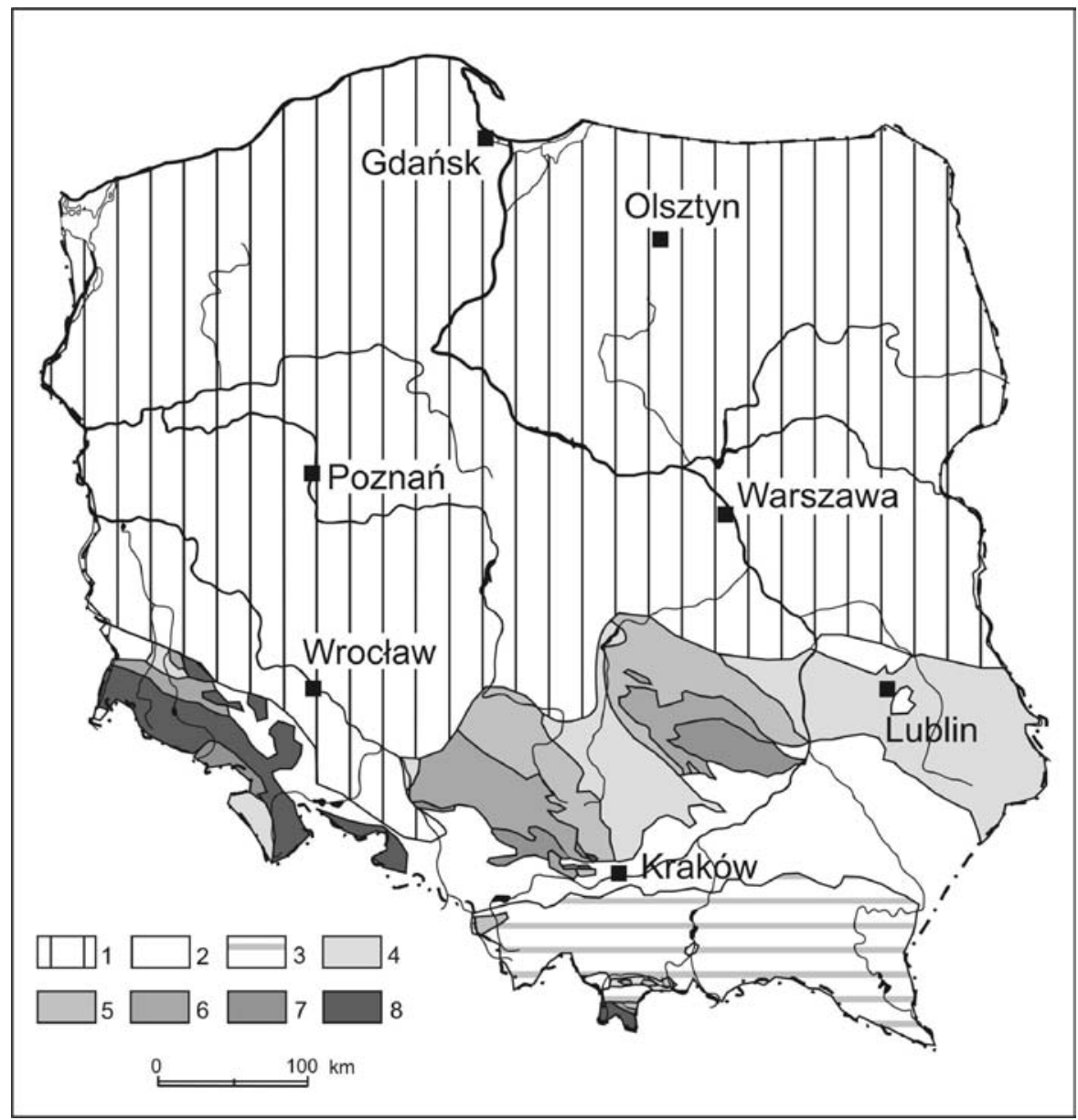

Figure 1. Geological map of Poland (after Ksiazkiewicz et al. 1965, modified and simplified). 1 - Thick blanket of glacial, fluvioglacial and fluvial Quaternary sediments, 2 - Paleogene and Neogene sedimentary rocks, 3 - Cretaceous and Paleogene flysch rocks of the Carpathians, 4-Cretaceous sedimentary rocks, 5-Jurassic sedimentary rocks, 6-Permian and Triassic sedimentary rocks, 7 - Cambrian to Carboniferous sedimentary rocks, 8 - Magmatic and metamorphic rocks.

of various shapes, types, levels of discharge, and water chemistry are usually found in large numbers on the outcrops of such rocks where these aquifers have not been drained by mining. Karstic, fissurekarstic, and fissured are the predominant types of springs draining Triassic, Jurassic, and Cretaceous limestones, dolomites, marls, as well as sandstones and quartzites. The discharge of these springs ranges from less than one to several hundred $\mathrm{dm}^{3} \cdot \mathrm{s}^{-1}$ (Dynowska, 1983; 1986).

The southern edge zones of Polish territory located along its southern boundary are occupied by two large mountain ranges: the Sudetes (Sudeten Mountains) and the Carpathians. The Sudetes constitute a Variscan massif formed of magmatic and metamorphic rocks which are partly overlaid by intra- and extra-basinal PermianMesozoic sedimentary-volcanic (pyroclastic) complexes. Currently, the mountain range is composed of tectonic blocks lifted up during the Neogene-Quaternary periods but affected earlier by deep weathering (etch planation) (Migon, 1999; Gawlikowska, 2000; Cwojdzinski and Kozdrój, 2007). The diversity of rocks and structures controls the diverse hydrogeological conditions, ranging from the karst aquifers of various sizes and shapes through the porous and/or fissured rock massifs (Carboniferous-Permian and Triassic clastics and pyroclastics, Cretaceous sandstones and siltstones) to poorly permeable magmatic and metamorphic rocks. This results in a great variety of spring sizes and types that drain karstic, porous, and fissured water bearing media (Stasko, 1996; Wojtkowiak, 2000; Rzonca et al., 2003).

The Alpine orogen of the Carpathian Mountains is composed of two parts: Outer and Inner Carpathians. The largest fragment of Polish part of the Carpathians belongs to the Outer Carpathians (called the Beskidy and Bieszczady Mountains) formed of CretaceousPaleogene flysch and tectonically shaped during the Neogene. The flysch sequence is composed of siliciclastic (sandstone, sandstone-conglomerate) and siliciclastic-clayey (sandstoneshale) series forming several structural (depositional tectonic) units extended (thrust over each other) to the north (Slaczka and Kaminski, 1998; Alexandrowicz and Poprawa, 2000; Malata, 2008). The pore-fissure groundwater reservoirs in the flysch clastics are drained by numerous springs but in most cases of small discharge (less than $1 \mathrm{dm}^{3} \cdot \mathrm{s}^{-1}$ ) (Waksmundzki, 1971). The Carpathians are known for numerous mineral springs, most of them discharging carbonated and sulfurous waters as well as waters containing carbon dioxide (Rajchel and Rajchel, 1999).

Conservation measures require a good understanding of the location of springs and their properties. Normally, one of the first steps is to catalogue information about the location and the natural, scientific, and educational value of each spring of interest, followed by the identification of potential as well as actual threats. In Poland, there is only a handful of publications of this kind and they cover mostly karst regions of the Slasko-Krakowska Upland and the Malopolska Upland in southern Poland (Dynowska, 1983), the Lubelska Upland and the Roztocze area in the east (Michalczyk, 1997), and the vicinity of the centrally located Polish city of Lódz (Moniewski, 2004). The dependence of springs on local geology and local landforms for the nature of their outflow and their discharge levels has produced a great diversity of springs in different parts of Poland (Dynowska, 1986).

Springs are among the features evidenced on the Detailed Geological Map of Poland, scale 1:50,000, the Detailed Hydrogeological Map of Poland, scale 1:50,000, as well as the GeologicalEconomic Map of Poland, scale 1:50,000 published by the Polish Geological Institute. The last map gives special attention to springs as potential subjects of legal protection for both economic and noneconomic reasons. Springs are also documented on the Hydrographic Map of Poland, scale 1:50,000, created by the Head Office of Geodesy and Cartography of Poland.

There exists an important need to create a database of springs in Poland. Siwek (2007) proposed an interactive database concept for upland springs. Such a database would contain information about each spring's geographic location, type, geology, form of legal protection, discharge, water temperature, and chemical composition. 


\section{Legal Framework for Spring Conservation in Poland}

In Poland, non-economic conservation is based on the provisions of the Nature Conservation Act passed in 2004. In terms of the conservation of springs, this is the only legislative act of its kind in Poland. The need for the conservation of springs is derived from the Conservation Act's "principle of rational management of inanimate natural resources" and proposes a conservative use of space and the preservation of its particularly valuable features. Springs, however, can also be protected as elements of one of the legal categories of conservation. Table 1 summarizes ten categories of nature conservation regulated by the Act.

Among the range of conservation categories defined by the Act, springs typically fall under "nature monuments", however, the protection of water and water relationships is also provided for by other categories of legal environmental protection (Items 1-5 and 9 in Table 1) or individual objects (6-8 and 10).

A protected area conservation status generally means that water relationships and landforms must not be altered. This high degree of protection, available only in national parks and nature reserves, is unconditional, i.e. independent of economic conditions and might, therefore, be regarded as sufficiently restrictive. In national parks, springs are legally protected just as are various other elements of nature and landscape. Springs are particularly abundant in national parks where they play important landscape-oriented roles. This is particularly true in the Tatra Mountains (Tatra NP), the SlaskoKrakowska Upland (Ojcowski NP), the Swietokrzyskie (Holy Cross) Mountains (Swietokrzyski NP) and the Sudetes (Giant Mountains NP, Stolowe Mountains NP).

In nature reserves, protection is afforded to nature in general but normally focuses on one of its components. In 2008 about 30 of the total number of 1423 nature reserves in Poland (Ochrona Srodowiska, 2008) were centered on springs as the main protected component. In the Central Polish Lowlands, examples include karstic springs located in Jurassic limestones in the Blue Springs (Niebieskie Zródla) Reserve on the Pilica River and in the Kozienicki Landscape Park (Mazowiecka Lowland). Outflows from Quaternary formations are protected in reserves on the Strazka River (Pomorskie Lakeland), on the Flinta River (Wielkopolskie Lakeland), and on the Lyna River (Mazurskie Lakeland). Upland reserves include a peat bog in the Tanwia Springs (Zródla Tanwi) Reserve in the Roztocze region and two reserves in the Malopolska Upland: the salt pan Owczary Reserve featuring a spring in the Nida Basin (Lajczak, 2001) and the forestlandscape Reserve Parkowe in the Wiercica River Valley, established in 1957 as one of the earliest reserves in Poland. Examples of reserves protecting mountain spring areas include: the springs of the Jasiolka River Reserve and the Barania Gora Reserve with the historically important springs of the Vistula River (in the Carpathian Mountains) (Alexandrowicz et al., 1975; 1992).

In landscape parks and protected landscape areas, spring protection is not unconditional and its effectiveness largely depends on local spatial development plans and on the activity and efficiency of the local nature conservation service. Numerous springs are legally protected in landscape parks in the Carpathian Mountains and the Carpathian Foothills, in complexes of Jurassic landscape parks, and in landscape parks of the Swietokrzyskie Mountains and the Nidzianska Basin.

The European Ecological Network Natura 2000 recognizes springs as protected natural habitats. Examples of areas covered by this environmental directive because of the springs they contain include: Cieszyn Calcareous Tuff Springs (Cieszynskie Zródla Tufowe) in the Carpathians and Blue Springs (Niebieskie Zródla) on the Pilica River as mentioned above.

Springs can also be regarded as geological features in documentation sites which are legally protected against damage and modification of local landforms or water relationships. There are five documentation sites with springs in Poland including the 
St. Vincent Kadlubek Spring (Zródlo Blogoslawionego Wincentego Kadlubka) near Sandomierz (Swietokrzyskie Mountains) which was characterized as a geological phenomenon in 1829 (Gagol and Urban, 2000).

Similar conservation and protection rules apply to landscapenature complexes and ecological sites established by resolutions of local authorities. In the landscape-nature complexes, springs are protected as components of the natural or cultural landscape in recognition of their outstanding aesthetic qualities while in ecological sites they are protected as ecosystems important for biodiversity.

Particularly valuable springs are afforded individual protection status as inanimate nature monuments.

\section{Springs Protected as Nature Monuments}

A nature monument (Table 1) is the oldest traditional and legal category of individual protection and it is the most popular in Poland. In 1949, it was introduced into Polish law by the Nature Protection Act and has been carried over by subsequent legislative changes. Legal provisions on nature monuments prevent their destruction or modification, change of landform or water relationship, other than those serving the purpose of nature protection or of rational forest, water or agricultural management. A nature monument is established by a regulation issued by a Voivode (Governor) who heads the local government in a given province or by a resolution of the local municipal council. Originally, cultural or aesthetic motivations played a significant role in conservation efforts. By the mid-1970s, however, only three springs had the status of nature monuments. St. Hubert's Spring (Zródlo sw. Huberta) in Wiktorów (Wielkopolska Lowland) was the first to be granted this status in 1955. It was followed in 1956 by the God's Gift Spring (Dar Bozy) in the BarlineckoGorzowski Landscape Park (western Wielkopolska Lakeland). Another early example of protected spring included site with the pulsating Murmuring Spring (Belkotka) in Iwonicz Zdrój (Carpathians).

By the early 1980s, only six of the total number of 13,500 nature monuments were springs (Fig. 2). In 1987, this status was granted to 27 springs, mostly ones in the Slasko-Krakowska and Malopolska Uplands. These springs were being explored by hydrologists from the Jagiellonian University with the research being headed by Dynowska (1983). Her research focused on the unique educational and landscape value of the springs located in the Uplands and stressed the need for conservation of these springs. In addition, a small number of springs located in the Swietokrzyskie Mountains were also granted legal protection including fissure outflows from virtually water-free Cambrian quartzite sandstones, karstic springs in Devonian limestones, spring areas linked to aquifers in Lower Triassic and

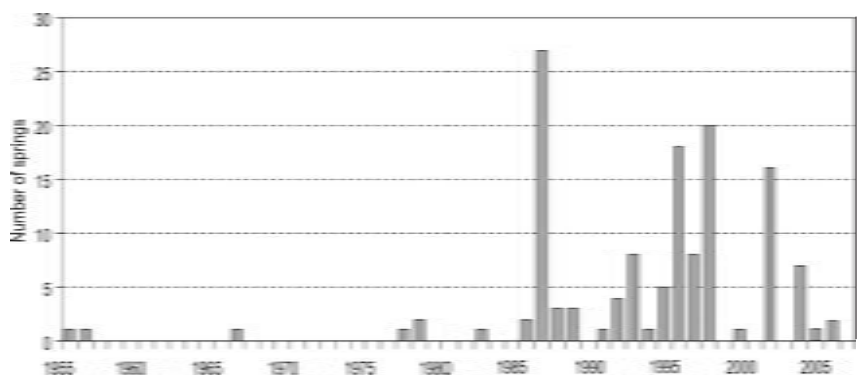

Figure 2. Number of springs recognized as monuments of nature in Poland (1955-2007).
Middle Jurassic sandstones, as well as Pleistocene saprolites of Paleozoic rocks (Wróblewski, 2000).

In the early 1990s, the number of springs with individual protection status rose to 42 (3.3\% of all monuments of inanimate nature). While the first research into springs in the Lubelska Upland and the Roztocze region dates back to the 1960s, the popularity of this research grew only starting in the 1990s. Researchers from Lublin explored this water-rich region and identified springs with high discharge rates (more than $100 \mathrm{dm}^{3} \cdot \mathrm{s}^{-1}$ ) and medium discharge rates $\left(10-100 \mathrm{dm}^{3} \cdot \mathrm{s}^{-1}\right)$ (Michalczyk, 1997). The substantial rates of discharge as well as the landscape and the scientific appeal of these springs stem from the hydrogeological properties of carbonate rocks - a network of tectonic fissures and considerable altitude differences in the local morphology. These scientific, educational, and landscape qualities, combined with cultural values, contributed to the designation of 37 of the springs studied as nature monuments, mostly between 1996 and 1998. The 1990s saw similar status being granted to a small number of springs in the Lower Vistula Valley and in the Pomorskie Lakeland. These include the St. Roch Spring (Zródlo sw. Rocha) on a slope of the Vistula Valley near Swiecie and large spring areas in the form of vast, semicircular basins on a lake shore near Czernica (eastern part of the Pomorskie Lakeland). In 1996, four springs in the western Central Lowlands were also formally granted legal protection.

The late $20^{\text {th }}$ century also saw conservation status granted to numerous Carpathian springs in view of the special mineral qualities of their waters and the risk of their potential economic usage connected with the accompanying destruction of their natural forms. In the flysch Carpathians, the sixteen most valuable natural springs yielding sulfideand carbonate-type waters were assigned protected status. Sulfurous water is characterized by the specific odor of sulfuric acid and the residue built up by colonies of bacteria while acidulous carbonatetype water occurs in conjunction with tectonic irregularity zones and is known for its "spa" qualities. The majority of these springs are found within the Popradzki Landscape Park and in the buffer zones of the Babiogórski and Magurski National Parks (Rajchel and Rajchel, 1999; Alexandrowicz and Poprawa, 2000).

In 1999/2000, while studying springs of the Slasko-Krakowska Upland and the Malopolska Upland (Chelmicki, 2001), researchers analyzed sites already recommended for protection and proposed new candidate sites. The resulting documentation helped sixteen springs located in the southern parts of these regions to receive monument status in 2002. Karst-fissure springs in these areas where Upper Jurassic and Upper Cretaceous carbonates occur are protected mainly for their unique landscape, educational, and ecological value. These areas are characterized by abundant groundwater within karst-type aquifers and karstic springs featuring high discharge rates (Fig. 3). They are attractive and dynamic landscape elements which also happen to actively build and modify unique landforms and microclimatic conditions that impact both biotic and abiotic components of the environment (Bascik et al., 2008). In 2004 - 5, in 2005 - 1, and in 2006 - 2 springs in the Slasko-Krakowska Upland were also granted nature monument status.

At the end of 2007 Poland had altogether 35,074 nature monuments (Ochrona Srodowiska, 2008) including 1961 inanimate nature monuments but just 134 springs $-0.4 \%$ of all monuments and approximately $6.8 \%$ of abiotic monuments. The individually protected springs are highly dispersed (Fig. 4). Decades of conservationist activity in the uplands with their rich water resources and interesting 


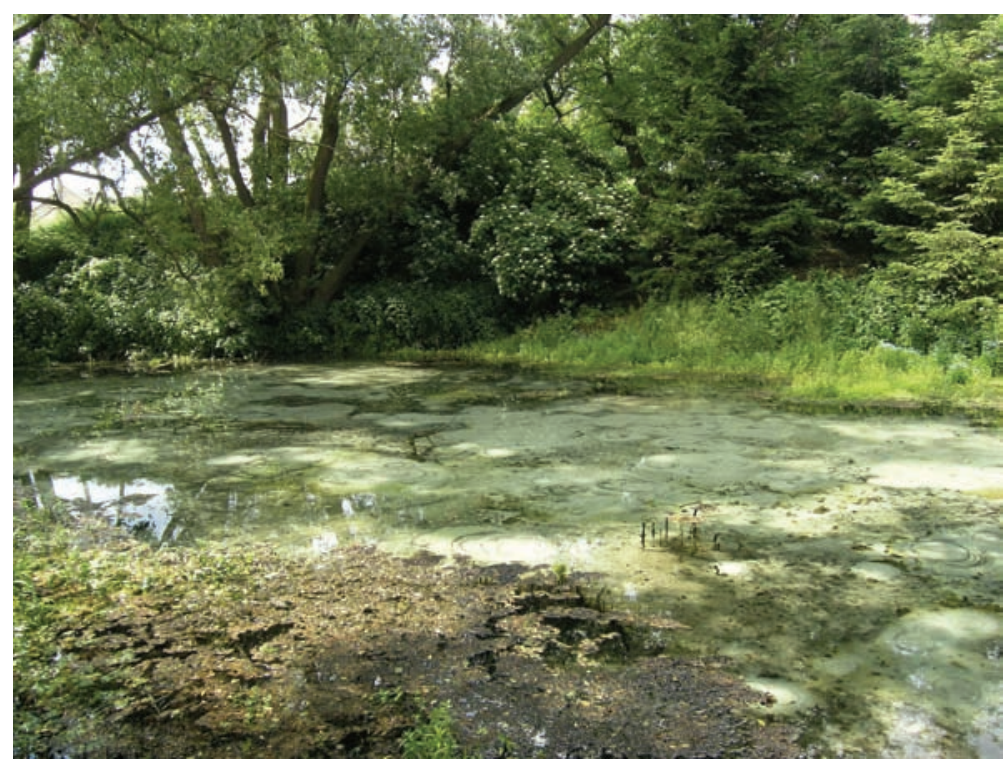

Figure 3. The Hydrografów Spring in the Dlubnianski Landscape Park (discharge: $85-135 \mathrm{dm}^{3 \cdot} \mathrm{s}^{-1}$ ). The bowl-type outflow is draining Cretaceous marls. The pulsating water and sand craters are visible on the bottom. Formerly, the spring water was used by a mill. Being a short distance from farmland makes this spring especially vulnerable to water contamination. outflows have resulted in this area having more than $64 \%$ of all the springs officially protected as "monuments of inanimate nature". Carpathian Mountain and Carpathian Foothill springs constitute approximately $18 \%$ of all individually protected springs in Poland while only one spring of this type is located in the Sudetes/Sudeten Foreland. The large Pomorskie Lake District contains 10\% of all spring nature monuments.

On the administrative map of Poland, most of the protected springs are found in the following provinces: Malopolskie (39\%), Lubelskie (28\%), and Swietokrzyskie (11\%). This distribution reflects the actual spring distribution within Polish geographic regions and their hydrological and landform diversity. This also suggests, however, that alongside natural factors, spring conservation relies heavily on the presence of active scientific centres and a positive attitude of local authorities towards nature conservation.

\section{Effectiveness of Spring Conservation and its Risks}

The greatest problem facing spring conservation is damage and pollution of the spring and its water. Spring cavities are most often destroyed when they are built-up (modified) for drinking water extraction. Other frequent reasons of the deterioration of the natural features of springs are: culture-related purposes, river training, and road or building construction. Spring water pollution is mostly linked to the improper management of the surroundings (e.g. applying chemical fertilizers), the destruction or the modification of the spring area, the littering of the spring and its surroundings, as well as excessive intervention in the water relationships both near the spring and in its sub-basin. The value of the natural landscape is also threatened by construction work in close proximity to a spring (Fig. 5). A lowering of the groundwater table may be difficult to detect but groundwater extraction or mine drainage measures may, in fact, lead to a complete drying up of a spring.

The granting of a legal protection status such as that of a nature monument, ecological site or documen-

Figure 4. Springs - monuments of nature in Poland. 

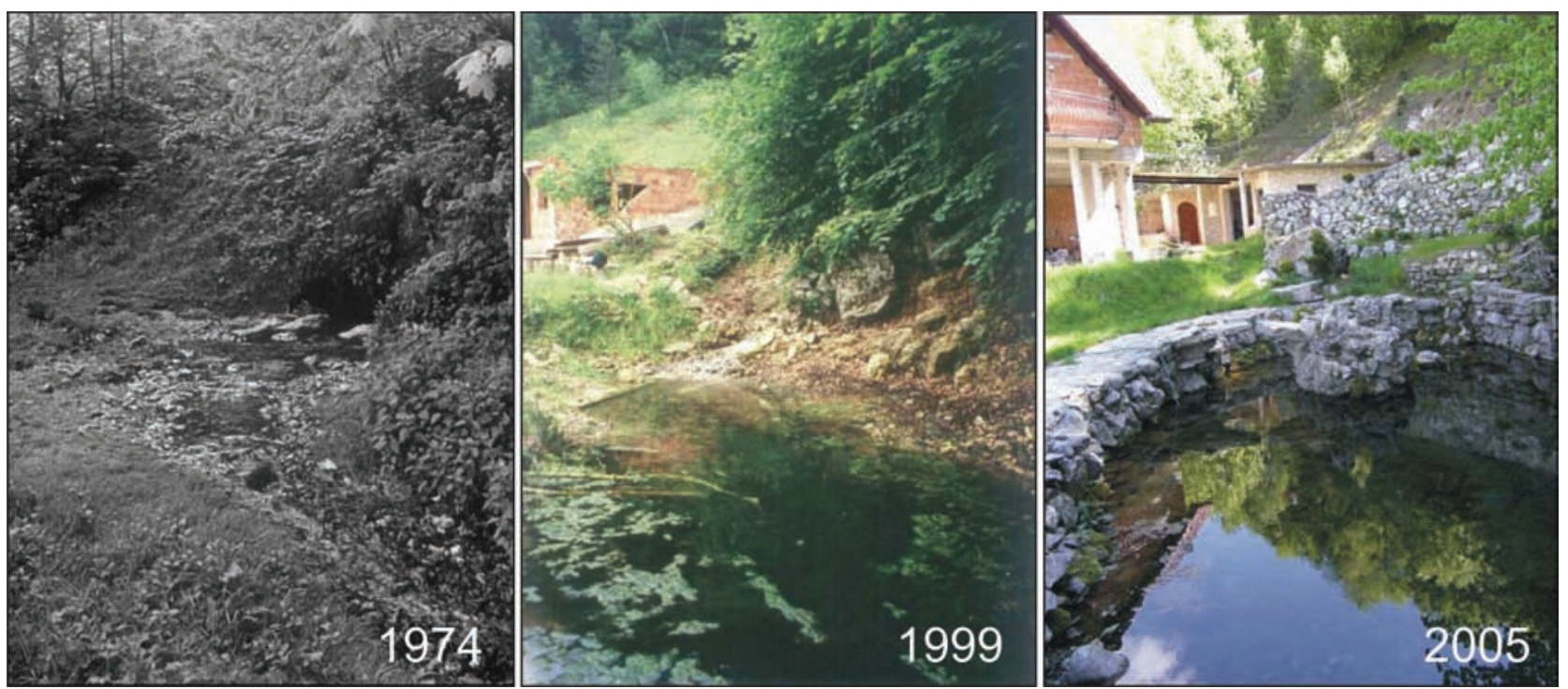

Figure 5. The Raclawki Spring in the Jurajski Landscape Park (Raclawki Valley). The natural outflow, first identified in 1974, was destroyed during building construction (late 1990s) and then surrounded with concrete and stone lining (2005).

tation site reduces the risk of spring destruction. Permitted economic and other types of human activity in protected areas (and their proximity) is restricted and these restrictions must be accepted by provincial nature conservation administrations and/or local authorities. Provisions protecting nature reserves and national parks are even more restrictive. In this case, legislative bans on landform modification, construction activity, and water relationship modifications are unconditional. In turn, water quality protection is provided by the Polish Water Law of 2001. In practice, however, it is difficult to entirely eliminate illegal activities such as the development of new housing, chemical and physical pollution, as well as landform modifications to spring cavities.

Spring research has demonstrated that some springs do require "renewal" and the application of certain measures to prevent degradation. There seems to be a need for each nature monument to have an individual mode of operation focusing primarily on its own conservation and the maintenance of its own natural features and their surroundings. Suitable signs should be placed next to designated monuments clearly stating their legal protection status. Protection measures designed for nature reserves and national parks are based on conservation plans (valid 20 years) containing hydrological instructions, among other things.

The effective protection of springs requires more than legal status. Indeed, the most important factor is education and awarenessbuilding within the general public about the objectives of spring protection. Society in general needs to be persuaded that natural springs are important witnesses of water circulation patterns in the ground (Earth's crust) and within nature as a whole. Moreover, people need to understand that springs are good indicators of groundwater quality and quantity. Consequently, the protection and monitoring of springs, their natural shape, and their natural environment is important not only from a scientific, educational, and nature (wildlife) point of view but, most of all, it is of fundamental importance for socialeconomic reasons. The preservation of the quality and the quantity of groundwater - as evidenced by springs - and the surface waters being recharged by springs is vital for human life and current as well as future economic activity.

The evidence of the usefulness of a conservationist approach emerged during the last few years when the provision of legal protection status for many springs was accompanied by successful campaigns by a number of nature preservation centres, local authorities, as well as environmental conservation services for building awareness of the importance of springs as components of natural heritage. Local governments have been quite helpful in developing educational materials containing information about valuable springs for use by various local communities and tourists who might become interested in helping to achieve conservationist goals if properly informed of the importance of spring conservation.

\section{Conclusions}

Spring conservation has recently gained in popularity in scientific circles that have come to recognize both the economic and natural significance of springs. The many facets of the existence and functioning of springs have made them a focus of interdisciplinary research including: hydrogeological, hydrological, hydrochemical, hydrobiological, cultural, landscape, and ecological. An interdisciplinary approach is indeed necessary for an accurate evaluation of the functioning of springs in nature and their economic potential (Bascik et al., 2008).

An integrated research approach should ideally lead to the taking stock of natural outflows of groundwater, the building of a database of springs, the charting of maps of springs featuring information about their various properties, and the recommendation of the most valuable of springs for legal protection. Indeed, spring conservation activities are particularly important with respect to the economic dimension of water and its extraction which is often a potential source of a conflict between humans and nature. For these reasons, all environmental protection and regional development programs, including local spatial development plans and municipal development strategies, should adopt a holistic approach to the protection of water and its springs both of which are important components of nature.

The importance of water protection has been highlighted by the fact that it is being dealt with by European and global legislative bodies. The principles of water management adopted in 1968 in Strasbourg and known as the European Charter on Water Resources 
remain valid to this day. The Charter states that water protection requires more intensive research, training of professionals, and the education of society. Springs are included as an element of geodiversity and geological heritage in the "Recommendation on conservation of the geological heritage and areas of special geological interest" adopted by the Committee of Ministers of the Council of Europe on May $5^{\text {th }}, 2004$. The recommendation points to the fundamental (scientific, cultural, aesthetic, landscape, economic, as well as intrinsic) value of natural resources which need to be preserved and handed down to future generations. In January 2008, at the World Economic Forum in Davos, business, political, and social leaders accepted that water conservation is among the most urgent of global issues.

\section{Acknowledgements}

Authors wish to thank Andrzej Kalemba for his help in completing the current list of protected springs.

\section{References}

Alexandrowicz, Z., Drzal, M. and Kozlowski, S., 1975, Katalog rezerwatów i pomników przyrody nieozywionej w Polsce (A catalogue of inanimate nature reserves and monuments in Poland). Studia Naturae, ser. B, vol. 26, pp. 298 (in Polish with English summary).

Alexandrowicz, Z., Kucmierz, A., Urban, J. and Oteska-Budzyn, J., 1992, Waloryzacja przyrody nieozywionej obszarów i obiektów chronionych w Polsce (Evaluation of inanimate nature of protected areas and objects in Poland. Panstwowy Instytut Geologiczny, Warszawa, 140 p. (in Polish with English summary).

Alexandrowicz, Z. and Poprawa, D. (Eds.), 2000, Ochrona georóznorodnosci w Polskich Karpatach (Geodiversity conservation in the Polish Carpathians). Panstwowy Instytut Geologiczny, Warszawa, 142 p. (in Polish with English summary).

Alexandrowicz, Z., Romeyko-Hurko, K. and Urban, J., 2004, Geology and relief of Poland in landscape protection. In: Parkes, M. (Ed.), Natural and cultural landscapes - the geological foundation: Proc. Conf. 9-11.09.2002, Dublin Castle, Royal Irish Academy, Dublin, pp. 175-178.

Ball, D.M., 2004, Mystical mythical Ireland; groundwater and the advantages of suspended disbelief. In: Parkes, M. (Ed.), Natural and cultural landscapes - the geological foundation: Proc. Conf. 9-11.09.2002, Dublin Castle, Royal Irish Academy, Dublin, pp. 205-208.

Barquin, J. and Scarsbrook, M., 2008, Management and conservation strategies for coldwater springs: Aquatic conservation: Marine and Freshwater Ecosystems, vol. 18, no. 5, pp. 580-591.

Bascik, M. and Chelmicki, W., 2002, Zródla - Przyroda, geografia, mistyka (Springs - Nature, geography, mysticism). In: Kultuniak, J. (Ed.): Rzeki. Kultura, cywilizacja, historia, 11, Wyd. Slask, Katowice, pp. 119-146 (in Polish with English summary).

Bascik, M., Chelmicki, W. and Siwek, J., 2008, Les sources comme indicateurs de la qualité de l'environnement en Pologne. In: Da Lage, A., Amat, J.P., Frérot, A.M., Guichard-Anguis, S., Julien-Laferrière, B., Wicherek, S.P. (Eds.), L'après-développement durable: espaces, nature, culture et qualité. Elipses, Paris, pp. 267-276.

Buraczynski, J., 1997, Roztocze. Budowa - rzezba - krajobraz (Geology, relief and landscape of Roztocze Upland). Univ. M. Curie-Sklodowska, Lublin, 72 p. (in Polish).

Cantonati, M., Bertuzzi, E. and Scalfi, A., 2005, CRENODAT (Biodiversity assessment and integrity evaluation of springs of Trentino - Italian Alps and longterm ecological research): Project design and preliminary results. Headwater 2005, Conference papers (CD).

Chelmicki, W. (Ed.), 2001, Zródla Wyzyny Krakowsko-Wielunskiej i Miechowskiej. Zmiany w latach 1973-2000 (Springs of the KrakowskoWielunska and Miechowska Uplands. Changes in 1973-2000). Instytut Geografii i Gospodarki Przestrzennej UJ. Kraków: 127 p. (in Polish with English summary).

Cwojdzinski, S. and Kozdrój, W., 2007, Sudetes. Geotourist guide. Pol. Geol. Inst., Warsaw, pp. 119-227 (accessed online March 2009: at http:// www.pgi.gov.pl/images/stories/NW/sudang.pdf)

Dingwall, P., Weighell, T. and Badman, T., 2005, Geological world heritage: a global framework. Protected Area Programme IUCN. Accessed online July 30, 2008: http://www.iucn.org/themes/wcpa/pubs/pdfs/heritage/ geology.pdf.

Dynowska, I. 1983, Zródla Wyzyny Krakowsko-Wielunskiej i Miechowskiej (Springs of the Krakowsko-Wielunska and Miechowska Uplands). Studia Osrodka Dokumentacji Fizjograficznej PAN, Oddzial Kraków, vol. 11, 244 p. (in Polish with English summary).

Dynowska, I., 1986, Regionalne zróznicowanie zródel w Polsce (Regional differentiation of springs in Poland). Folia Geographica, series Geographica-Physica, vol. 18, pp. 5-30 (in Polish with English summary).

Fac-Beneda, J. and Hryniszak, E., 2007, Wyplywy wód podziemnych u podnózy krawedzi pradolinnych (Groundwater outflows along lower edge of proglacial stream valley). In: Jokiel, P., Moniewski, P. and Ziulkiewicz, M. (Eds.): Zródla Polski. Wybrane problemy krenologiczne: Wydzial Nauk Geograficznych Uniwersytetu Lódzkiego. Lódz, pp. 129134 (in Polish with English summary).

Gagol, J. and Urban, J., 2000, Jerzy Bogumil Pusch prekursorem ochrony geologicznych stanowisk dokumentacyjnych (Jerzy Bogumil Pusch as a precursor of geological documentation sites). Przeglad Geologiczny, vol. 48, no. 1, pp. 55-56 (in Polish).

Gawlikowska, E., 2000, Ochrona georóznorodnosci na Dolnym Slasku (Geodiversity conservation of the Lower Silesia). Panstwowy Instytut Geologiczny, Warszawa 72 p. (in Polish with English summary).

Gray, M., 2003, Geodiversity: valuing and conserving abiotic nature. John Wiley \& Sons Ltd. Chichester, 448 p.

Groever, W., Bierbaum, T. and Homburg, I., 1996, Erfahrungen mit der Umsetzung des quellschtzkoncpets im kreis Guetersloh. Crunoecia, vol. 5, pp. 161-166.

Hartnett, F.M. (Ed.), 2000, Florida's springs: strategies for protection and restoration. Florida Dept. of Env. Protection, Tallahassee, Florida, $59 \mathrm{p}$.

Kondracki, J., 2000, Geografia regionalna Polski (Regional geography of Poland). Wyd. Nauk. PWN, Warszawa, 440 p (in Polish).

Kozina, K., 2008, Obiekty przyrody nieozywionej na Liscie Swiatowego Dziedzictwa UNESCO (Abiotic properties on the World Heritage List of UNESCO). Przeglad Geologiczny, vol. 56, no. 3, pp. 198-207 (in Polish).

Ksiazkiewicz, M., Samsonowicz, J. and Rühle E., 1965, Zarys geologii Polski (Outline of geology of Poland). Wyd. Geol., Warszawa, 380 p. (in Polish)

Lajczak, A., 2001, Zródla mineralne Niecki Nidzianskiej (Mineral springs of the Nida Basin). Czasopismo Geograficzne, vol. 72, no. 2, pp. 151-184 (in Polish).

Malata, T., 2008, Developmentt of Polish Flysch Carpathians revealed in outcrops and landscapes. Przeglad Geologiczny, vol. 56, no. 8/1, pp. 688-691.

Mariolakos, I., 1998, The geomythological geotope of Lerni Springs. Geologica Balcanica, vol. 28, no. 3-4, pp. 101-108.

Matyszkiewicz, J., 2008, The Cracow-Czestochowa Upland (Southern Poland) - The Land of White Cliffs and Caves, Przeglad Geologiczny, vol. 56, no. $8 / 1$, pp. 647-652.

Michalczyk, Z. (Ed.), 1997, Zródla Wyzyny Lubelskiej i Roztocza (Springs of the Lublin Upland and the Roztocze region). Acta Universitatis Lodziensis, Folia Geographica, series Geographica-Physica, vol. 2, pp. 79-93 (in Polish with English summary).

Migon, P., 1999, Znaczenie glebokiego wietrzenia w morfogenezie Sudetów (Deep weathering in landscape development of the Sudetes). Przeglad Geograficzny, vol. 71, no. 1-2, pp. 59-75 (in Polish, with English summary). 
Mojski, J.E., 2005, Ziemie polskie w czwartorzêdzie. Zarys morfogenezy. (Polish lands in the Quaternary period. Outline of morphogenesis). Panstwowy Instytut Geologiczny, Warszawa, 404 p. (in Polish).

Moniewski, P., 2004, Zródla okolic Lodzi (Springs near Lódz). Acta Geographica Lodziensia, vol. 87, 140 p. (in Polish with English summary).

Ochrona Srodowiska (Yearbook of Environmental Protection), 2008, Glówny Urzad Statystyczny, Warszawa, 556 p.

Paczynski B. and Sadurski A. (Eds.), 2007, Hydrogeologia regionalna Polski (Regional hydrogeology of Poland), I - Wody slodkie (Fresh waters), Panstwowy Instytut Geologiczny, Warszawa, 542 p. (in Polish).

Radwanek-Bak, B. and Bak, B., 2008, The Middle Vistula River section as a geotourist attraction. Przeglad Geologiczny, vol. 56, no. 8/1, pp. 639546.

Rajchel, L. and Rajchel, J., 1999, Karpackie zródla wód mineralnych i specyficznych - pomnikami przyrody nieozywionej (Carpathian springs of mineral and therapeutic waters - monuments of inanimate nature). Przeglad Geologiczny, vol. 47, no. 10, pp. 911-919 (in Polish with English summary).

Rzonca, B., Buczynski, S., Krasnicki, S., 2003, Wody krasowe wybranych obszarów Ziemi Klodzkiej (Karst waters in the selected areas of the Klodzko region). In: Contemporary problems of hydrogeology, vol. 11, part I, pp. 215-220 (in Polish with English summary).

Sada, D.W., Williams, J.E., Silvey, J.C., Halford, A., Ramakka, J., Summers, P. and Lewis, L., 2001, Riparian area management: A guide to managing, restoring, and conserving springs in the Western United States. Technical Reference 1737-17. Bureau of Land Management, Denver, Colorado, $70 \mathrm{p}$.

Scarsbrook, M., Barquin, J. and Gray, D., 2007, New Zealand coldwater springs and their biodiversity. Science for Conservation, vol. 278, 72 p.

Siwek, J., 2007, Baza danych o zródlach na Wyzynie Slaskiej i Malopolskiej - uwagi metodyczne (Database of springs of the Slaska and Malopolska

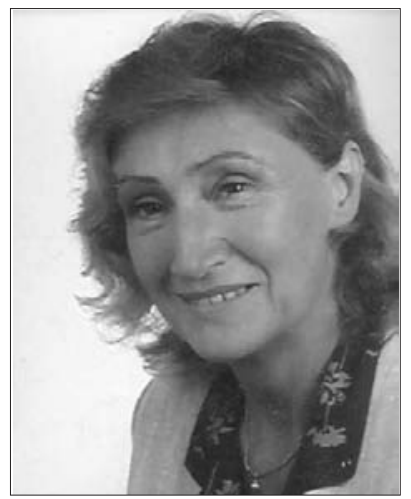

Maria Bascik - Researcher at the Department of Hydrology, Institute of Geography and Spatial Management, Jagiellonian University in Kraków, Poland. Her interests are focused on landscape evaluation, springs conservation, and hydrological cartography. Author and coauthor of regional monographs on Polish mountains, encyclopedic geographic dictionaries, and hydrological maps.

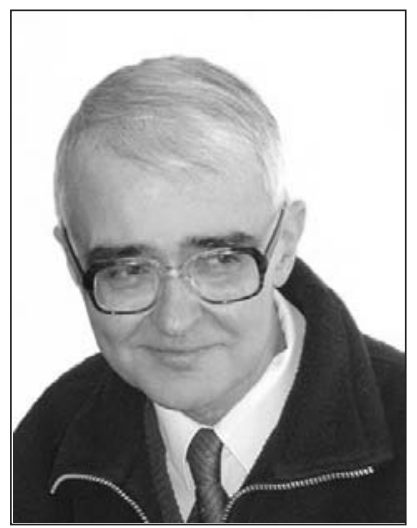

Wojciech Chelmicki - Professor of Physical Geography, Head of the Department of Hydrology, Institute of Geography and Spatial Management, Jagiellonian University in Kraków, Poland. His interests cover groundwater - surface water interactions, human impact on water circulation, water chemistry dynamics and hydrological cartography. $\mathrm{He}$ is the national correspondent for Poland in the European Network of Experimental and Representative Basins (ERB).
Uplands - methodological remarks). In: Jokiel, P., Moniewski, P. and Ziulkiewicz, M. (Eds.), Zródla Polski. Wybrane problemy krenologiczne. Wydzial Nauk Geograficznych Uniwersytetu Lódzkiego, Lódz, pp. 7884 (in Polish with English summary).

Slaczka, A., Kaminski, M.A., 1998, A guidebook to excursions in the Polish Flysch Carpathians. Special Publication, no. 6, Grzybowski Foundation, pp. 171.

Slomka, T. 2008, Geodiversity of Poland. Przeglad Geologiczny, vol. 56, no. 8/1, pp. 584-587.

Stasko S., 1996, Wody podziemne w skalach krystalicznych na podstawie badan wybranych obszarów Sudetów polskich (Ground water in the crystalline rocks in the light of the research in the selected regions of the Sudeten Mts., Acta Univ. Wratisl., no. 1870, Prace Geol.-Minarol., vol. 53, 86 p. (in Polish with English summary).

Springer, A.E. and Stevens, L.E., 2009, Spheres of discharge of springs. Hydrogeology Journal, 17, pp. 83-93.

Urban, J. and Gagol, J., 2008, Geological heritage of the Swietokrzyskie (Holy Cross) Mts (central Poland). Przeglad Geologiczny, vol. 56, no. 8/1, pp. $618-628$

Waksmundzki K., 1971, Zmiennoœæ naturalnych wyplywów wody podziemnej w górskich obszarach fliszowych (Variability of natural outflows of ground water in the flysch mountain areas), Zesz. Nauk UJ, Prace Geogr., vol. 29, pp. $87-94$ (in Polish with English summary).

Wojtkowiak A., 2000, Rezim zródel obszarów krystalicznych Sudetów Zachodnich (Hydrological regime of springs in the crystalline regions of the Western Sudeten Mts.), Biul. PIG, 390, pp. 167-206 (in Polish with English summary).

Wróblewski T., 2000, Ochrona georóznorodnosci w regionie swietokrzyskim (Geodiversity conservation in the Góry Swietokrzyskie region). Panstwowy Instytut Geologiczny, Warszawa, 88 p. (in Polish with English summary).

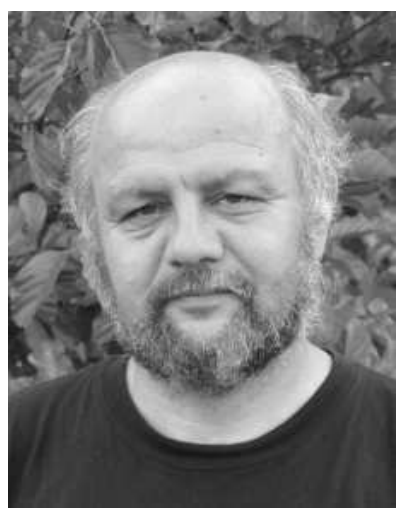

Jan Urban - Geologist at the Institute of Nature Conservation, Polish Academy of Sciences in Kraków, Poland. The main field of his activity is scientific-educational evaluation and the practical protection of abiotic objects. His scientific work is focused on studies of paleokarst features, karst and non-karst caves, rock formations, as well as historic mines. The human approach to the inanimate nature and natural resources currently and in the past is a matter of his special interest. 